journal home page:http://chimie-biologie.ubm.ro/carpathian_journal/index.html

\title{
EFFECT OF PROCESSING ON BETA CAROTENE, ASCORBIC ACID AND CHLOROPHYLL RETENTION OF SPINACH AND MINT
}

\author{
Pinki Saini $^{1 *}$, Priyanka Singh ${ }^{1}$, Anchal Singh ${ }^{1}$ and Urvashi Srivastava ${ }^{1}$ \\ Centre of Food Technology, Science Faculty Campus University of Allahabad Prayagraj, 211002, \\ $U P$, India \\ *pspinki55@gmail.com
}

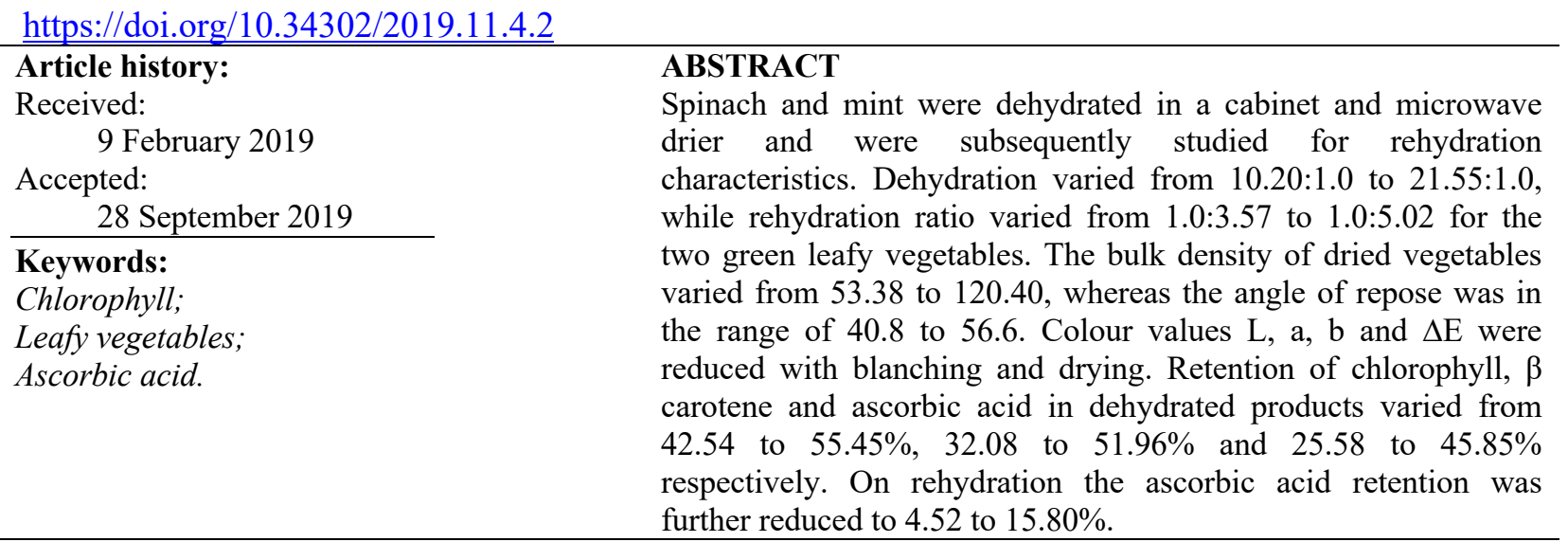

\section{Introduction}

Green leafy vegetables have unique place among vegetables because of there color, flavor and health benefit. They boost coronary health since they are surprisingly low in fat and high in dietary fibre. The beneficial nutrients present in leafy vegetables include folic acid, vitamin $\mathrm{C}$, potassium and magnesium. They also play host to a wide variety of phytochemicals, such as lutein, beta-cryptoxanthin, zeaxanthin, and beta-carotene.

Drying is a method of food preservation that works by removing water from the food, which prevents the growth of microorganisms and decay. By drying process, it restrict the wastage of over produced leaves, preserve the macro and micro nutrients of leaves and make available leaves after the season. Due to high production and high nutritional value, but short storage life due to high moisture content it is necessary to remove moisture by drying and increase the shelf life of spinach and mint leaves. Dehydrated vegetables are simple to use and have a longer shelf life than fresh vegetables (Chauhan and Sharma 1993, Gupta et al., 2013). Kuppuswamy and Rao (1970) reported that to obtain high-quality dehydrated vegetables, the drying process should allow effective retention of color, flavor, texture, taste and nutritive value. Mint and spinach are rich in iron, b-carotene, ascorbic acid and chlorophyll. The current study was undertaken to assess the effect of processing on the physicochemical properties of mint and spinach.

\section{Material and methods}

\subsection{Raw materials}

Spinach and mint used for this investigation has been purchased from the local market of Allahabad, Uttar Pradesh, India. 


\subsection{Drying}

Stalks of spinach, mint were removed, washed and chopped. Chopped stalks were blanched in water $(95 / 2 \mathrm{~min})$ followed by dip in potassium metabisulfite solution $(5 \mathrm{~g} / \mathrm{L})$ for 1 min. Blanched vegetables were dehydrated in a cabinet drier consisting of $0.4 \times 0.840 \times .95 \mathrm{~m}$ stainless steel inner chamber , $5 \mathrm{~kW}$ heater and a fan to circulate air inside the chamber at $65 \pm 3 \mathrm{C}$ for $5 \mathrm{~h}$. The blanched vegetables were also subjected to microwave drying at $640 \mathrm{~W}$ for $6 \mathrm{~min}$ and $10 \mathrm{~min}$ respectively for spinach and mint. Mass of the material was noted at every stage. Experiments were carried out in duplicate.

\subsection{Rehydration}

Rehydration was carried out by steeping the dried samples $(5 \mathrm{~g})$ in water $(120 \mathrm{ml})$ at $65 \mathrm{C}$ for $40 \mathrm{~min}$ for hot water rehydration (HWR) and at $27 \mathrm{C}$ for $2 \mathrm{~h}$ for cold water rehydration (CWR).

\subsection{Dehydration and Rehydration Ratio}

Dehydration and rehydration ratio was calculated by dividing the weight of the fresh or rehydrated sample by the weight of the dried sample.

\subsection{Bulk and True density, Angle of repose}

Dried sample of know weight was placed into a measuring cylinder, and its volume was noted to compute bulk density. A weighed amount of dehydrated sample was added to a measuring cylinder containing a known volume of toluene and its rise in volume per unit mass gave true density. The angle between the horizontal axis and slope of heap of the dried sample was measured with a protractor to obtain the angle of repose.

\subsection{Color Measurement}

Visual color was measured using Hunter colorimeter (X-rite) in term of L (lightness), a (redness), and $\mathrm{b}$ (yellowness and blueness). The values were used to compute $\tan ^{-1}(\mathrm{~b} / \mathrm{a})$ and $\Delta \mathrm{E}=\sqrt{\mathrm{L}^{2}+\mathrm{a}^{2}+\mathrm{b}^{2}}$

\subsection{Moisture}

Moisture content of spinach and mint was determined by using the hot air oven drying method at $110 \mathrm{C}$ for $2 \mathrm{~h}$ (AOAC 1990).

\section{8. $\beta$-carotene}

A sample (2 gm) was extracted with acetone and then transferred to a separating funnel containing 10 to $15 \mathrm{ml}$ of petroleum ether (Rangana 1986).

\subsection{Ascorbic acid}

The sample was extracted with (3\%) metaphosphoric acid and titrated against standardized 2, 6 dichlorophenol indophenol dye till the appearance of light pink color which persisted for $15 \mathrm{sec}$ (Ranganna 1986).

\subsection{Chlorophyll}

A sample (10) was mixed with magnesium carbonate $(0.1 \mathrm{~g})$ and extracted with acetone in a pestle mortar using purified sand until the residue become colorless (Ranganna 1986). Volume of extracted was made to $50 \mathrm{ml}$ and this was taken in a separating funnel along with petroleum ether $(50 \mathrm{ml})$ water was transferred from the sides of the separating funnel until the water layer was of all fat soluble pigment $\mathrm{s}$. the water layer was drained off, and the ether layer was washed 5-10 times with distilled water and anhydrous sodium sulphate (3gm) is put on filter paper in funnel and pass the extracted through it and was diluted by petroleum ether to $100 \mathrm{ml}$ in volumetric flask, and this OD was measured at 660.0 and $642.5 \mathrm{~nm}$ using a UV visible spectrophotometer (Thermoscientific Pvt. Ltd.).

\subsection{Statistical Analysis}

The mean and SD of moisture content, bulk density, angle of repose, colour values, chlorophyll content, $\beta$-carotene and ascorbic acid were calculated. One way analysis of variance and least significant difference were employed to check the significant effect $(\mathrm{P}<0.05)$ of dehydration, rehydration, blanching and drying on spinach and mint (Cochran and Cox, 1957). 


\section{Results and Discussion}

\subsection{Dehydration and Rehydration of Green Leafy Vegetables}

Moisture content in fresh mint and spinach was $86.16 \%$ and $93.91 \%$ on w.b., respectively. Mint contained more solids than spinach. The weight of fresh green leafy vegetable was reduced from 100.0 to 88.95 and $67.32 \mathrm{~g}$ on blanching for mint and spinach, respectively (Table 1). Higher weight loss due to blanching was observed in spinach followed by and mint. Loss of weight during blanching was due to loss of solids and water. Statistical analysis revealed that moisture content decreased $(\mathrm{P}<$ $0.05)$ on blanching in all the three vegetables. Spinach and mint were then dried in a cabinet drier and microwave oven. Studies showed that the moisture content of the cabinet dried product was lower than microwave dried products. The weight of the product was also lower in the cabinet drier, which indicated higher solid loss during cabinet drying. Negi and Roy (2000) had reported that sun drying of leafy vegetables seemed to present a disadvantage of more solid losses during drying. The dehydration ratio for cabinet-dried mint and spinach were 11.24:1.0 and 21.55:1.0 respectively (Table 2 ). The dehydration ratio in microwave drying was lower than that of cabinet drying. Low dehydration ratio implied that yield was more in microwave dried products. Statistical analysis showed that the dehydration ratios of microwave dried mint and spinach were $(\mathrm{P}<0.05)$ lower than those of sun dried. Gupta and Nath (1984) have also reported higher dehydration ratio in sun-dried samples than that of cabinet-dried samples. Previous studies showed that dehydration ratio was 22:1 in cabinet-dried spinach (Lal 1944).

Dried samples were rehydrated in cold and hot water. Weight of the cabinet and microwave dried mint was increased to 21.18 and $17.87 \mathrm{~g}$ in CWR and to 24.45 and $20.60 \mathrm{~g}$ in HWR, respectively, per 100-g fresh green leafy vegetable. Similarly weight of the cabinet and microwave dried spinach was also increased to 18.24 and $21.55 \mathrm{~g}$ in CWR and to 24.50 and $22.44 \mathrm{~g}$ in HWR, respectively, per 100 -g fresh green leafy vegetable (Table 1). Moisture content of the rehydrated vegetables varied between 75.15 and $80.75 \%$. The rehydration ratio in cabinet-dried mint was the highest both in cold and hot water (Table 2). Rehydration ratio in microwave dried mint was the lowest both in cold and hot water. However, cabinet dried spinach samples showed rehydration ratio in the range of 1.0:3.64 1.0:4.35. Statistical analysis showed $(\mathrm{P}<0.05)$ different rehydration ratios. Bajaj et al. (1993) gave different blanching treatments to get better quality dried fenugreek product for which rehydration ratio ranged from 1.0:5.9 to 1.0:7.2. The effect of blanching, pricking and drying air temperature on the rehydration ratio of peas dehydrated in fluidized bed dryer showed that unpricked samples had a rehydration ratio less than 1.0:3.0, while pricked samples had a rehydration ratio greater than 1.0:3.2 (Narain and Kanawade, 1993). Thus, the rehydration ratio of spinach, mint and mustard was lower than dried fenugreek but was higher than peas.

Table 1. Effect of dehydration and rehydration on yield and moisture content of mint and spinach $(n=3)$

\begin{tabular}{|c|c|c|c|c|}
\hline \multirow{2}{*}{$\begin{array}{c}\text { Processing } \\
\text { condition }\end{array}$} & \multicolumn{2}{|c|}{ Mint } & \multicolumn{2}{c|}{ Spinach } \\
\cline { 2 - 5 } & $\begin{array}{c}\text { Yield g/100g } \\
\text { raw material }\end{array}$ & $\begin{array}{c}\text { Moisture } \\
\text { Content (\%) }\end{array}$ & $\begin{array}{c}\text { Yield g/100g } \\
\text { raw material }\end{array}$ & $\begin{array}{c}\text { Moisture } \\
\text { Content (\%) }\end{array}$ \\
\hline Fresh & 100 & $86.16 \pm 0.99^{\mathrm{a}}$ & 100 & $93.91 \pm 1.19^{\mathrm{a}}$ \\
\hline Blanched & 88.95 & $84.79 \pm 0.09^{\mathrm{b}}$ & 67.32 & $91.94 \pm 1.08^{\mathrm{b}}$ \\
\hline Cabinet dried & 8.5 & $6.43 \pm 0.35^{\mathrm{g}}$ & 4.64 & $4.57 \pm 0.07^{\mathrm{g}}$ \\
\hline Microwave dried & 9.8 & $8.46 \pm 0.15^{\mathrm{f}}$ & 5.20 & $5.14 \pm 0.13^{\mathrm{f}}$ \\
\hline CWR & \multicolumn{3}{|c}{} \\
\hline
\end{tabular}




\begin{tabular}{|c|c|c|c|c|}
\hline Cabinet dried & 21.18 & $76.22 \pm 0.35^{\mathrm{e}}$ & 18.24 & $75.21 \pm 0.98^{\mathrm{e}}$ \\
\hline Microwave dried & 17.87 & $80.55 \pm 1.25^{\mathrm{c}}$ & 21.55 & $80.75 \pm 0.22^{\mathrm{c}}$ \\
\hline HWR & 24.45 & $76 . .20 \pm 1.54^{\mathrm{e}}$ & 24.50 & $75.15 \pm 1.45^{\mathrm{e}}$ \\
\hline Cabinet dried & 20.60 & $78.5 \pm 21.48^{\mathrm{d}}$ & 22.44 & $79.48 \pm 1.20^{\mathrm{d}}$ \\
\hline Microwave dried &
\end{tabular}

CWR: Cold Water Rehydration; HWR: Hot Water Rehydration

Means in a column, within processing condition, not followed by a common letter are significantly different at $\mathrm{P}<0.05$

Table 2. Dehydration and rehydration ratios, bulk density and angle of repose of cabinet dried and microwave dried mint and spinach $(n=3)$

\begin{tabular}{|c|c|c|c|c|c|}
\hline \multirow[t]{2}{*}{ Sample } & \multirow{2}{*}{$\begin{array}{l}\text { Dehydration } \\
\text { ratio }\end{array}$} & \multicolumn{2}{|c|}{ Rehydation ratio } & \multirow{2}{*}{$\begin{array}{l}\text { Bulk density } \\
\left(\mathrm{Kg} / \mathbf{m}^{3}\right)\end{array}$} & \multirow[t]{2}{*}{ Angle of repose $\left(^{\circ}\right)$} \\
\hline & & Cold water & Hot water & & \\
\hline $\begin{array}{l}\text { Cabinet dried } \\
\text { mint }\end{array}$ & $11.24: 1.0^{\mathrm{c}}$ & $1.0: 4.23$ & $1.0: 5.02$ & $53.380 \pm .091^{\mathrm{d}}$ & $50.5 \pm 2.87^{b}$ \\
\hline $\begin{array}{l}\text { Cabinet dried } \\
\text { spinach }\end{array}$ & $21.55: 1.0^{\mathrm{a}}$ & $1.0: 3.64$ & $1.0: 4.35$ & $102.38 \pm 0.07^{c}$ & $40.8 \pm 2.53^{\mathrm{d}}$ \\
\hline $\begin{array}{l}\text { Microwave } \\
\text { dried mint }\end{array}$ & $10.20: 1.0^{\mathrm{d}}$ & $1.0: 3.57$ & $1.0: 4.12$ & $105.15 \pm 0.06^{\mathrm{b}}$ & $56.6 \pm 1.24^{\mathrm{a}}$ \\
\hline $\begin{array}{l}\text { Microwave } \\
\text { dried spinach }\end{array}$ & $19.23: 1.0^{\mathrm{b}}$ & $1.0: 3.84$ & $1.0: 4.49$ & $120.40 \pm 0.02^{\mathrm{a}}$ & $43.2 \pm 2.44^{c}$ \\
\hline
\end{tabular}

Means in a column, within processing condition, not followed by a common letter are significantly different at $\mathrm{P}<0.05$ Means without superscript are non significant

\subsection{Bulk Density and True Density}

Microwave dried samples had more bulk density than cabinet-dried samples (Table 2). Microwave dried spinach had the highest bulk density $(120.40 \mathrm{~kg} / \mathrm{m} 3)$, whereas mint had bulk density in the range of $53.380-105.15 \mathrm{~kg} / \mathrm{m} 3$. Cabinet-dried spinach also had higher bulk density of $102.38 \mathrm{~kg} / \mathrm{m} 3$ than mint. Statistical analysis revealed that dried spinach had $(\mathrm{P}<$ 0.05 ) higher bulk density than mint. The bulk density of fresh spinach was $224 \mathrm{~kg} / \mathrm{m} 3$, and that of cabbage was $449 \mathrm{~kg} / \mathrm{m} 3$ (Mohsenin 1970). The bulk density of rapeseed was observed to be $585.1-612.1 \mathrm{~kg} / \mathrm{m} 3$ at three different moisture contents (Sedat et al. 2004). Results show that products produced in the current study were fluffy, having low bulk density.

\subsection{Angle of Repose}

Angle of repose was the highest for microwave dried mint $\left(56.6^{\circ}\right)$ and the lowest for cabinet-dried spinach $\left(40.8^{\circ}\right)$ (Table 2). The cabinet-dried mint and spinach both had lower angle of repose than the microwave dried one.
Difference in angle of repose would be due to the difference in the surface properties of the dried vegetables. Statistical analysis showed (P $<0.05$ ) different values of angle of repose of dehydrated leafy vegetables. The angle of repose was reported to be $39.7^{\circ}$ at $3.46 \%$ moisture content for wheat grains (Fowler and Wyatt 1960). Results show that the angle of repose values were near to those of wheat grains.

\subsection{Colour}

There was decrease in greenness after blanching and drying (Table 3). In the case of mint, a value changed from an initial value of 6.17 in fresh sample to -6.07 after blanching and to -2.58 after cabinet drying. It indicated a decrease in greenness with blanching and drying. In fresh mint, L value was 32.53 , which decreased to 28.81 after blanching, 17.51 after cabinet drying and 25.26 after microwave drying. Thus, lightness ( $\mathrm{L}$ value) also decreased in fresh samples and was least in cabinet-dried samples. $\Delta \mathrm{E}$ value for fresh mint was 31.84 , which decreased to 25.16 after blanching. After 
cabinet drying and microwave drying of mint, $\Delta \mathrm{E}$ value was 18.35 and 20.59 , respectively. Therefore, $\Delta \mathrm{E}$ value was the maximum for fresh samples, and it decreased after blanching and drying. For fresh mint, $\tan ^{-1} \mathrm{~b} / \mathrm{a}$ value was 0.995, and after blanching, it was -0.835 . After cabinet drying and microwave drying, $\tan ^{-1} \mathrm{~b} / \mathrm{a}$ value was -1.038 and -1.189 , respectively. Similar results were observed in the case of spinach. Statistical analysis did not show significant difference in color. Color degradation kinetics of spinach, mustard leaves and mixed puree was studied in respect to both visual green color (-a value) and total color ( $\mathrm{L}$ x [-a] x b) (Ahmed et al. 2002). It was observed that during thermal processing, apart from Hunter -a value, both $\mathrm{L}$ and $\mathrm{b}$ values also decreased with time at a given temperature. Rocha et al. (1993) studied the effects of pretreatments and drying conditions on drying rate and on the chlorophyll and color retention ( $L$, $a, b$ value) of air-dried basil. $L$ and $b$ values decreased with the increase in drying temperature. So, the results of the current study are in accordance with Ahmed et al. (2002) and Rocha et al. (1993).

Table 3. Color values of mint and spinach at different drying stage $(n=3)$

\begin{tabular}{|c|c|c|c|c|c|}
\hline $\begin{array}{l}\text { Processing } \\
\text { condition }\end{array}$ & $L$ & $a$ & $b$ & Tan-1 b/a & $\begin{array}{l}\Delta E=\sqrt{L^{2}+a^{2}} \\
+b^{2}\end{array}$ \\
\hline \multicolumn{6}{|l|}{ Mint } \\
\hline Fresh & $32.53 \pm 0.17^{b}$ & $-6.17 \pm 0.05^{b}$ & $13.02 \pm 0.24^{\mathrm{a}}$ & $-0.995 \pm 0.33^{c}$ & $31.84 \pm 1.17^{b}$ \\
\hline Blanched & $28.81 \pm 1.30^{\mathrm{c}}$ & $-6.07 \pm 0.76^{b}$ & $10.62 \pm 0.22^{c}$ & $-0.835 \pm 1.25^{\mathrm{a}}$ & $25.16 \pm 2.05^{d}$ \\
\hline Cabinet dried & $17.51 \pm 0.68^{\mathrm{g}}$ & $-2.58 \pm 0.31^{\mathrm{e}}$ & $7.83 \pm 0.39^{\mathrm{e}}$ & $-1.038 \pm 0.35^{b c}$ & $18.35 \pm 0.05^{\mathrm{f}}$ \\
\hline Microwave dried & $25.26 \pm 3.43^{d}$ & $-2.53 \pm 0.27^{\mathrm{e}}$ & $6.23 \pm 0.33^{f}$ & $-1.189 \pm 0.21^{\mathrm{ab}}$ & $20.59 \pm 1.15^{\mathrm{e}}$ \\
\hline \multicolumn{6}{|l|}{ Spinach } \\
\hline Fresh & $34.91 \pm 0.87^{\mathrm{a}}$ & $-6.04 \pm 0.12^{b}$ & $11.81 \pm 0.31^{\mathrm{b}}$ & $-0.850 \pm 0.16^{\mathrm{a}}$ & $35.25 \pm 0.85^{\mathrm{a}}$ \\
\hline Blanched & $24.28 \pm 1.15^{\mathrm{e}}$ & $-7.14 \pm 0.31^{\mathrm{a}}$ & $9.16 \pm 0.30^{d}$ & $-0.815 \pm 0.24^{a}$ & $28.83 \pm 2.50^{\mathrm{c}}$ \\
\hline Cabinet dried & $22.33 \pm 2.32^{\mathrm{f}}$ & $-3.13 \pm 0.12^{\mathrm{d}}$ & $6.44 \pm 0.18^{\mathrm{f}}$ & $-1.105 \pm 0.09^{b}$ & $18.17 \pm 0.54^{\mathrm{f}}$ \\
\hline Microwave dried & $24.10 \pm 0.79^{\mathrm{e}}$ & $-4.75 \pm 0.80^{c}$ & $8.10 \pm 0.44^{\mathrm{e}}$ & $-1.275 \pm 0.58^{\mathrm{a}}$ & $20.75 \pm 0.38^{\mathrm{e}}$ \\
\hline
\end{tabular}

$\mathbf{L}$, lightness /darkness; a, redness +greenness; $\mathbf{b}$, yellowness and blueness

Means in a column, within processing condition, not followed by a common letter are significantly different at $\mathrm{P}<0.05$

\subsection{Chlorophyll}

Chlorophyll content in fresh mint and spinach was 181.92 and $100.24 \mathrm{mg} / 100 \mathrm{~g}$ raw material on w.b., respectively. Chlorophyll content was higher in mint $(1,426.18 \mathrm{mg} / 100 \mathrm{~g}$ raw material, d.b.) than spinach (Table 4). Fresh spinach contained $1,310 \quad \mathrm{mg}$ chlorophyll/100 g raw material (d.b.) (Negi and Roy 2000). The chlorophyll retention after blanching was higher in spinach followed by mint. The chlorophyll retention was the maximum in microwave drying as compared to cabinet drying. Chlorophyll content was
$1,085.24$ and $1,095.23 \mathrm{mg} / 100 \mathrm{~g}$ raw material (d.b.) in cabinet and microwave dried spinach, respectively. Retention of chlorophyll after dehydration was found to be in the range of $42.54-55.45 \%$. Retention of chlorophyll in kachi, dhantu and honagone upon dehydration was in the range of 52-71\% (Madhura and Majumdar 2001). Chlorophyll content was compared to greenness (-a value) determined by Hunter colorimeter. As the chlorophyll content decreased after blanching and drying, similarly, greenness (-a value) also decreased after blanching and drying in spinach and mint. 
Table 4. Effect of blanching and drying on chlorophyll, beta carotene and ascorbic acid content per $100 \mathrm{gm}$ raw material (d.b) of mint and spinach

\begin{tabular}{|c|c|c|c|c|c|c|}
\hline $\begin{array}{l}\text { Processing } \\
\text { condition }\end{array}$ & $\begin{array}{c}\text { Chlorophyll } \\
\text { mg/100 g } \\
\text { RM(d.b) }\end{array}$ & $\begin{array}{c}\text { Overall } \\
\text { retention } \\
(\%)\end{array}$ & $\begin{array}{c}\text { } \beta \text { - carotene } \\
\text { mg/100g } \\
\text { RM(d.b) }\end{array}$ & $\begin{array}{c}\text { Overall } \\
\text { retention } \\
(\%)\end{array}$ & $\begin{array}{l}\text { Ascorbic } \\
\text { acid } \\
\text { mg/100g } \\
\text { (d.b) }\end{array}$ & $\begin{array}{c}\text { Overall } \\
\text { retention } \\
(\%)\end{array}$ \\
\hline \multicolumn{7}{|l|}{ Mint } \\
\hline Fresh & $1,426.18 \pm 7.56^{\mathrm{a}}$ & 100 & $35.40 \pm 0.03^{\mathrm{a}}$ & 100 & $285.33 \pm 2.84^{\mathrm{a}}$ & 100 \\
\hline Blanched & $1,010.83 \pm 10.52^{b}$ & 55.21 & $27.21 \pm 1.91^{\mathrm{b}}$ & 68.10 & $173.35 \pm 2.19^{\mathrm{b}}$ & 48.98 \\
\hline Microwave dried & $822.52 \pm 1.38^{c}$ & 48.81 & $17.18 \pm 1.05^{\mathrm{c}}$ & 51.96 & $108.09 \pm 0.19^{c}$ & 37.54 \\
\hline Cabinet dried & $742.33 \pm 1.18^{\mathrm{d}}$ & 42.54 & $10.61 \pm 1.75^{\mathrm{f}}$ & 42.15 & $86.67 \pm 0.20^{\mathrm{d}}$ & 25.58 \\
\hline \multicolumn{7}{|l|}{ CWR } \\
\hline Microwave dried & $718.15 \pm 2.84^{\mathrm{e}}$ & 40.85 & $16.34 \pm 0.94^{\mathrm{d}}$ & 48.73 & $25.28 \pm 2.35^{\mathrm{e}}$ & 9.20 \\
\hline Cabinet dried & $692.20 \pm 1.12^{\mathrm{f}}$ & 39.45 & $10.02 \pm 2.24^{\mathrm{g}}$ & 40.06 & $17.44 \pm 0.7^{\mathrm{g}}$ & 6.32 \\
\hline \multicolumn{7}{|l|}{ HWR } \\
\hline Microwave dried & $685.72 \pm 1.89^{\mathrm{g}}$ & 38.82 & $14.29 \pm 2.27^{\mathrm{e}}$ & 45.88 & $18.84 \pm 0.08^{f}$ & 5.37 \\
\hline Cabinet dried & $635.85 \pm 2.20^{\mathrm{h}}$ & 33.52 & $6.83 \pm 0.25^{\mathrm{h}}$ & 38.05 & $12.43 \pm 0.17^{\mathrm{h}}$ & 4.52 \\
\hline \multicolumn{7}{|l|}{ Spinach } \\
\hline Fresh & $1,385.80 \pm 1.32^{\mathrm{a}}$ & 100 & $38.55 \pm 0.65^{a}$ & 100 & $135.89 \pm 6.42^{\mathrm{a}}$ & 100 \\
\hline Blanched & $1,243.14 \pm 4.52^{b}$ & 57.58 & $35.67 \pm 1.04^{b}$ & 58.15 & $103.09 \pm 0.20^{b}$ & 51.73 \\
\hline Microwave dried & $1,095.23 \pm 2.48^{c}$ & 55.45 & $23.33 \pm 2.15^{\mathrm{c}}$ & 50.16 & $91.67 \pm 0.15^{\mathrm{c}}$ & 45.85 \\
\hline Cabinet dried & $1,085.24 \pm 1.65^{\mathrm{d}}$ & 50.56 & $11.04 \pm 1.80^{\mathrm{g}}$ & 32.08 & $65.25 \pm 0.10^{\mathrm{d}}$ & 32.58 \\
\hline \multicolumn{7}{|l|}{ CWR } \\
\hline Microwave dried & $1,066.36 \pm 1.85^{\mathrm{e}}$ & 48.75 & $22.33 \pm 0.08^{d}$ & 45.81 & $35.57 \pm 1.41^{\mathrm{e}}$ & 15.80 \\
\hline Cabinet dried & $1,045.56 \pm 2.21^{\mathrm{f}}$ & 44.85 & $14.09 \pm 2.25^{\mathrm{f}}$ & 30.67 & $20.60 \pm 0.58^{f}$ & 9.21 \\
\hline \multicolumn{7}{|l|}{ HWR } \\
\hline Microwave dried & $1,042.38 \pm 1.29^{\mathrm{g}}$ & 46.56 & $17.48 \pm 1.25^{\mathrm{e}}$ & 41.33 & $19.16 \pm 0.21^{\mathrm{g}}$ & 5.87 \\
\hline Cabinet dried & $975.78 \pm 3.75^{\mathrm{h}}$ & 42.89 & $9.55 \pm 0.45^{\mathrm{h}}$ & 22.51 & $17.48 \pm 1.25^{\mathrm{h}}$ & 8.98 \\
\hline
\end{tabular}

CWR: Cold Water Rehydration; HWR: Hot Water Rehydration; RM: Raw material; d.b,: Dry Basis

Means in a column, within processing condition, not followed by a common letter are significantly different at $\mathrm{P}<0.05$

In CWR, loss of chlorophyll in dried samples was less as compared to HWR. After the CWR process, chlorophyll content in cabinet dried mint and spinach was 692.20 and 1.45.56 mg/100 g raw material (d.b.), respectively, while for microwave dried mint and spinach, the chlorophyll content was 718.15 and $1,066.36 \mathrm{mg} / 100 \mathrm{~g}$ raw material (d.b.). There was an increased loss of chlorophyll upon rehydration in hot water. Chlorophyll content after HWR process in cabinet-dried mint and spinach was 635.85 and $975.78 \mathrm{mg} / 100 \mathrm{~g}$ raw material (d.b.), whereas in microwave dried mint and spinach, it was 685.72 and $1042.38 \mathrm{mg} / 100 \mathrm{~g}$ raw material (d.b.), respectively. Overall retention of chlorophyll in CWR and HWR varied between $39.45-48.75$ and $33.52-46.56 \%$, respectively. Statistical analysis of chlorophyll content of mustard at different stages showed a $(\mathrm{P}<0.05)$ reduction or loss on blanching and drying.Asimilar trend was also observed in mint and spinach. Schwartz and Lorenzo (1991) observed that chlorophyll is sensitive to heat. Chlorophyll degradation in processed foods and plant tissues has been reviewed by Heaton and Maragoni (1996).

\section{6. $\beta$-carotene}

$\beta$-carotene was higher in fresh spinach (38.55 mg/100 g raw material, d.b.) than mint. The $\beta$-carotene content of common leafy 
vegetables ranged from as low as $0.12 \mathrm{mg} / 100$ $\mathrm{g}$ to as high as $5.580 \mathrm{mg} / 100 \mathrm{~g}$ raw material on w.b. (Kowsalya et al. 2001). The $\beta$-carotene content in fresh mint was found to be 34.49 $\mathrm{mg} / 100 \mathrm{~g}$ (d.b.) (Kowsalya et al. 2001). After blanching, the $\beta$-carotene content was found to be $27.21 \mathrm{mg} / 100 \mathrm{~g}$ raw material (d.b.) in mint and $35.67 \mathrm{mg} / 100 \mathrm{~g}$ raw material (d.b.) in spinach. Overall retention of $\beta$-carotene was $68.10 \%$ in mint and $58.15 \%$ in spinach after blanching.

The $\beta$-carotene content in spinach was higher during microwave drying, i.e., 23.33 $\mathrm{mg} / 100 \mathrm{~g}$ raw material (d.b.), than cabinet drying (11.04 mg/100 g raw material [d.b.]). In mint the $\beta$-carotene content after microwave and cabinet drying was 17.18 and 10.61 $\mathrm{mg} / 100 \mathrm{~g}$ raw material (d.b.), respectively. After cabinet drying, the $\beta$-carotene retention varied between 32.08 and $42.15 \%$, and after microwave drying, it was 50.16-51.96\%. Devadas et al. (1978) revealed that sun drying of green leafy vegetables and their subsequent storage for 1 year resulted in $10-60 \%$ retention of $\beta$-carotene. Carotene is degraded by a free radical oxidation mechanism, and the degree of oxidation depends on drying temperature (Harris and Karmas 1975). Retention of $\beta$ carotene after sun drying ranged between 22.26 and $26.08 \%$. Kowsalya et al. (2001) reported $\beta$ carotene retention after sun drying from 17.7 to $32.4 \%$. The results are in accordance with the range given by earlier studies. In the earliest study by Negi and Roy (2000), $\beta$-carotene retention after drying in spinach ranged from 20 to $40 \%$. In the present study, $\beta$-carotene retention after drying in spinach varied between 32.08 and $51.96 \%$. So, the results are in accordance with previous studies.

After the CWR process, the $\beta$-carotene content in microwave and cabinet-dried mint was 16.34 and $10.02 \mathrm{mg} / 100 \mathrm{~g}$ raw material (d.b.). In microwave and cabinet-dried spinach after the CWR process, the $\beta$-carotene content was 22.33 and $14.09 \mathrm{mg} / 100 \mathrm{~g}$ raw material (d.b.). There was considerable effect on $\beta$ carotene content after the HWR process. The $\beta$ carotene content in microwave and cabinet- dried mint was 14.29 and $6.83 \mathrm{mg} / 100 \mathrm{~g}$ raw material (d.b.) after the HWR process. In microwave and cabinet-dried spinach $\beta$ carotene content was 17.48 and $9.55 \mathrm{mg} / 100 \mathrm{~g}$ raw material (d.b.) after the HWR process. After the CWR process, there was not much effect on the $\beta$-carotene content of dried samples, but after the HWR process, there was loss of $\beta$-carotene from the dried samples. Heating for long times can decrease $\beta$-carotene content via reactions like oxidation and isomerization (Speak et al. 1988). Statistical analysis indicates that there was significant $(\mathrm{P}<$ 0.05 ) reduction in $\beta$-carotene content as a result of blanching, drying and rehydration. These results are in agreement with Uadal and Sagar (2008) who have studied the retention of $\beta$ carotene in dehydrated amaranth, fenugreek and spinach.

\subsection{Ascorbic Acid}

Ascorbic acid content in a fresh sample was higher in mint $(285.33 \mathrm{mg} / 100 \mathrm{~g}$ raw material [d.b.]) than spinach (Table 4). Ascorbic acid after blanching was higher in mint (173.35 $\mathrm{mg} / 100 \mathrm{~g}$ raw material, d.b.) as compared with spinach $(103.09 \mathrm{mg} / 100 \mathrm{~g}$ raw material, d.b.). Overall retention of ascorbic acid after blanching was $48.98 \%$ in mint and $51.73 \%$ in spinach. Badify and Onayemi (1987) reported that ascorbic acid retention was $42-53 \%$ in water blanching. The aforementioned results are also in this range.

There was reduction in ascorbic acid content after drying; however, retention was maximum in microwave drying followed by cabinet drying. In cabinet and microwave dried mint, the ascorbic acid content was 86.67 and $108.09 \mathrm{mg} / 100 \mathrm{~g}$ raw material (d.b.), while in cabinet and microwave dried spinach, the ascorbic acid content was 65.25 and 91.67 $\mathrm{mg} / 100 \mathrm{~g}$ raw material (d.b.). Retention of ascorbic acid ranged from 32.08 to 42.15 $\mathrm{mg} / 100 \mathrm{~g}$ raw material (d.b.) in cabinet dried leafy vegetables, while it was 91.67 to 108.09 $\mathrm{mg} / 100 \mathrm{~g}$ raw material (d.b.) in microwave dried leafy vegetables, which corresponds to $25.58-32.58 \%$ and $37.54-45.85 \%$. Lakshmi 
and Vimala (2000) reported that retention of ascorbic acid ranged from 15 to $31 \%$ in sundried leafy vegetables and from 37 to $49 \%$ in cabinet-dried leafy vegetables. Thus, in the present study, retention of ascorbic acid is comparable to previous reported values.

Ascorbic acid content in cabinet and microwave dried mint after CWR was 17.44 and $25.28 \mathrm{mg} / 100 \mathrm{~g}$ raw material (d.b.), respectively whereas in spinach, it was 20.60 and $35.57 \mathrm{mg} / 100 \mathrm{~g}$ raw material (d.b.). After rehydration in hot water, there was increased loss in ascorbic acid in microwave dried samples in comparison to cabinet-dried samples. The ascorbic acid content after HWR in cabinet and microwave dried mint was 12.43 and $18.84 \mathrm{mg} / 100 \mathrm{~g}$ raw material (d.b.). Statistical analysis showed a $(\mathrm{P}<0.05)$ reduction in ascorbic acid content as a result of leaching and thermal degradation. Overall retention of ascorbic acid in HWR and CWR varied between 12.43-19.16 and 17.44-35.57 $\mathrm{mg} / 100 \mathrm{~g}$ raw material (d.b.), respectively. The retention of ascorbic acid in leafy vegetables was in the range of $4.52-15.80 \%$. The losses in ascorbic acid could be attributed to increased activities of ascorbic acid oxidizing enzymes, leaching and destruction (Tapadia et al. 1995).

\section{Conclusions}

Two green leafy vegetables were selected to study the effect of processing on their physical and chemical properties. Dehydration ratio was high in the case of cabinet dried samples as compared to microwave dried samples. Rehydration ratio was in the range between 1.0:3.57 and 1.0:5.02. Bulk density varied between 53.38 and $120.40 \mathrm{~kg} / \mathrm{m} 3$, and its values were higher in the case of microwave dried samples compared to cabinet-dried samples. Ascorbic acid content was found to be higher in fresh mint $(285.33 \mathrm{mg} / 100 \mathrm{~g}$ raw material, d.b.) followed by spinach. The $\beta$ carotene content in the fresh sample was found to be higher in spinach $(38.55 \mathrm{mg} / 100 \mathrm{~g}$ raw material, d.b.) followed by mint, whereas the chlorophyll content was higher in mint $(1,426.18 \mathrm{mg} / 100 \mathrm{~g}$ raw material, d.b.) followed by spinach. Ascorbic acid retention after blanching was in the range of 48.98$51.73 \%$. After drying and rehydration, ascorbic acid retention was found to be in the range of $25.58-45.85$ and $4.52-15.80 \%$, respectively. The increased loss of ascorbic acid could be attributed to leaching, oxidation, effect of heat and light. Retention of chlorophyll after drying varied between 42.54 and $55.45 \%$ whereas after rehydration, chlorophyll retention was in the range of $33.52-48.75 \%$.

\section{References}

Ahmed, J., Kaur, A., Shivhare, U. (2002). Color degradation kinetics of spinach, mustard leaves and mixed puree. Journal of Food Science, 67(3), 1088-1091.

AOAC. (1990) Official Methods of Analysis of the Association of Official Analytical Chemists, 15th Ed., Assoc. of Official Analytical Chemists, Arlington, VA. 1990.

Badify, G.I.O., Onayemi, O. (1987) Effect of blanching and drying methods on the nutritional and sensory quality of leafy vegetables. Plant Foods Human Nutrition, 37, 291-298.

Bajaj, M., Aggarwal, P., Minhas, K.S., Sidhu, J.S. (1993) Effect of blanching treatments on the quality characteristics of dehydrated fenugreek leaves. Journal of Food Science and Technology, 30(3), 196-198.

Chauhan, S.K., Sharma, C.R. Development of instant dehydrated saag. Beverage and Food World, 20(4), 25-26.

Cochran, W.G., Cox, G.M. (1957) Experimental Designs, John Wiley and Sons, Inc., New York.

Fowler, R.T., Wyatt, F.A. (1960) The effect of moisture content on the angle of repose of granular solids. Australian Journal of Chemical Engineering, 1, 5-8.

Gupta, R.G., Nath, N. (1984) Drying of tomatoes. Journal of Food Science and Technology, 21(6), 372-376.

Gupta, S., Gowri, B. S., Lakshmi, A. J., \& Prakash, J. (2013). Retention of nutrients in green leafy vegetables on dehydration. Journal of Food Science and 
Technology, 50(5),918-925.

http://doi.org/10.1007/s13197-011-0407-z

Harris, R.S., Karmas, E. (1975) Nutritional Evaluation of Food Processing, AVI Publishing Company, Westport, CT.

Heaton, J.W., Maragoni, A.G. (1996) Chlorophyll degradation in processed food and renascent plant tissues. Trends in Food Science and Technology, 7, 8-15.

Kowsalya, S., Chandrashekhar, U., Balasasirekha, R. (2001) B-carotene retention in selected green leafy vegetables subjected to dehydration. Indian Journal of Nutrition and Dietetics, 38, 374-383.

Kuppuswamy, A., Rao, G. (1970) Dehydration of green peas. Journal of Food Science and Technology, 11, 60-63.

Lakshmi, B., Vimala, V. (2000) Nutritive value of dehydrated green leafy vegetables. Journal of Food Science and Technology, 37(5), 465-471.

Lal, G. (1944) Dehydration of vegetables. Punjab Fruit J. 8(29), 38-41.

Madhura, C.V., Majumdar, T.K. (2001) Processing effect on colour and vitamins of green leafy vegetables. Journal of Food Science and Technology, 38(1), 79-81.

Mohsenin, N.N. (1970) Physical Properties of Plant and Animal Materials, Gorden and Breach Science Publishers, New York, NY.

Narain, M., Kanawade, V.L. (1993) Effect of pretreatment and drying air temperature on quality of peas dehydrated in fluidized bed dryer. Journal of Food Science and Technology, 30(2), 118-120.

Negi, P.S., Roy, S.K. (2000) Effect of blanching and drying methods on bcarotene, ascorbic acid and chlorophyll retention of leafy vegetables. LebensmittelWissenschaft \& Technologie, 33, 295-298.

Ranganna, S. (1986) Handbook of Analysis and Quality Control for Fruit and Vegetable Products, Tata McGraw Hill Publications Company Limited, New Delhi, India.

Rocha, T., Lebert A., Marty-Audouin, C. (1993) Effect of pre-treatments and drying conditions on drying rate and color retention of basil. LebensmittelWissenschaft \& Technologie 26, 456-463.

Schwartz, S.J., Lorenzo, T.V. (1991) Chlorophyll stability during continuous aseptic processing and storage. Journal of Food Science, 56, 1059-1062.

Sedat, C., Jamir, M., Huseyin, O., Ozdeno. (2004) Physical Properties of Rapeseed, Department of Agricultural Machinery, Faculty of Agriculture, Selcuk University, Konya, Turkey.

Speak, A.J., Speak, S.S., Schreurs, W.H.P. (1988) Total carotenoid and B-carotene contents of Thai vegetables and effect of processing. Food Chemistry, 27, 245-257.

Tapadia, S.B., Arya, A.B., Rohini Devi, P. (1995) Vitamin-C contents of processed vegetables. Journal of Food Science and Technology, 32(6), 513-515.

Uadal, S., Sagar,V.R. (2008). Influence of packaging and storage temperature on the quality of dehydrated selected leafy vegetables. Journal of Food Science and Technology, 45, 450-453. 